\title{
Ecumenical Movement and Interreligious Dialogue
}

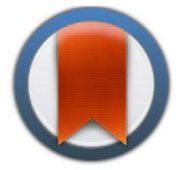

ARTICLE INFO

\section{Article history:}

Received 28 March 2019

Received in revised form 1 May

Accepted 10 June 2019

Available online 30 June 2019

doi: 10.18638/dialogo.2019.5.2.10

Keywords:

interfaith; movement; ecumenicity; dialogue; overlapping; Christianity; Islam; Mosaism; religions; acceptance;

harmony; fusion; unity;

\author{
Fr. Lect. Cosmin Tudor CIOCAN, PhD \\ Ovidius University of Constanţa \\ Faculty of Orthodox Theology \\ Romania \\ cosmin.ciocan@univ-ovidius.ro
}

\begin{abstract}
For me, as a teacher in a theological faculty, the discussion about ecumenical movement and interfaith usually crosses roads with colleagues or students. There is no occasion in which these two are not placed under the same roof, overlaid or confused. That is why the sudden preoccupation to settle this topic as clear as I can so that it can stand for a groundwork when researching about this relationship. Their overlapping is probably the most common hindrance and at the same time indictment for the DIR (abbr., interreligious dialogue) movement of its "least-connoisseurs", namely that DIR is a new figment of promoting ecumenical globalization. After I myself faced in classroom students with these assumptions, I thought it is appropriate to add this chapter and explain why DIR is nothing of what the ecumenical movement wanted to be.
\end{abstract}

\section{INTRODUCTION ON THE ECUMENICAL MOVEMENT}

The ecumenical movement, which appeared in the religious landscape of the 2oth century (1910) $)^{[1]}$, has as many partisans as fierce enemies. Its purpose refers to the efforts towards the visible and organic unity of the various Christian denominations in a certain form. The "Christian" dimension is not, however, the only delimitation besides DIR as it was mentioned on various occasions when the overlapping of terms was desired. This is because the idea of the expansion of the globalizing goal beyond the boundaries of Christianity through a possible "interreligious ecumenism" [2] has been propagated as well. This new desideratum that is postulated by the nowadays quasi-pluralist coexistence, by the widening of the space of dialogue, from within Christianity towards all other religions and religious movements, has created the impression (wrongly, for our concerns) that the ecumenical movement has turned into a movement of interreligious dialogue. ${ }^{[3]}$ We will return to this immutable supposition immediately. 


\section{A. The Unity of faith}

The ideal of a unity of faith that the Ecumenical Movement displays has supporters who say they are pursuing a common biblical creed and a singular divine precept. The unity of the Church has often been a controversial subject. It is certain that all Scriptures are infused with this belief as desideratum, which again signifies the idealism of the idea instead of the reality of its historical existence. Among the reasons why "the Church" must fight for unity, there are also the New Testament teaching passages that teach us specifically that the Church should be or it will be One: the prayer of Jesus (John 17: 20-23). This divine desideratum expressed in the desire of Christ should have led to His ecclesial heritage. Instead, many Pauline epistles resume the same theme and try to impose or propose it as a stimulant to communities in the Apostolic Age. Paul urges the Ephesians to "Make every effort to keep the unity of the Spirit through the bond of peace" (Ephesians 4.3) reminding them that "you have been called to the one hope of your calling" (verses 4-6). The unity of the Church is a recurring theme in the Pauline exhortations and at the same time considered natural whenever its analogy with the divine uniqueness is made. "There is only one Lord, one faith, one baptism. There is one God and Father of all, who is above all, who works through all, and in all" (verse 5-6).

Due to the insistence on this theme/ analogy between divine uniqueness and unity of faith, otherwise unspecified and unclarified nowhere, we understand that it has never been possible to realize and that the individualism of receiving the unique Word has never led to an inexpressive conformism; on the contrary. The image of the Church as the body of Christ is another capital argument in favor of the unity of faith and it is omnipresent in the theological writings of gender. "Just as the body, though one, has many members, and as all the members of the body, though there are many, are one body, so it is with Christ. For we were all baptized by one Spirit so as to form one body ..." (1 Corinthians 12: 12-13). Stig Hanson comments on the passage: "One Body refers to the Church as the Body of Christ, this is the opinion of most who are studying the Bible positively. This Body must be one because Christ is one and Christ cannot be divided." [4] It is only from these recurrent and apostrophic appeals of Paul to the present day that the divine hope and the ideal of prayer dominated the pragmatic historical reality "in the field," which leads to a diverse palette of given interpretations of this unity. First historical, then judicial, until the conciliar, organic and even spiritual unity $^{[5]}$ that shows how focused and great was and still is the concern that the unity manifests itself through a genuine organic union.

\section{$B$. The organic unity and the autonomy of the congregations}

Definitely this conception of unity of the Church(s) is even more utopian when it comes to a globalizing ${ }^{[6]}$, merging of separate identities into a single, unique and parent organization, where all the differences are abandoned. We are not talking here of the inter-confessional dialogue meetings of the ecumenical missionary associations (CEB 1948, NCCC, ACCC 1941, ICCC, etc.), but about the organisms actually formed on missionary principles out of the bodies of other denominations. [ "] "Membership and ordination are common. When denominations unite in this way, there is often also a merging of local congregations. A first example of the organizing unity is the United Church of Canada, a singular denomination formed in 1925 by the union of Methodists, Presbyterians, and Congregationalists. Another example is the Church of South India."[ 8] Practically, 
this ecumenical vision of organic unity aims ultimately to combining all Christian, Roman Catholic, Orthodox, and Protestant churches into a universal Church of Christ (UCC).

As explained by various theologians, ${ }^{[9]}$ this organic unity must, however, take account of some local autonomy, to avoid falling into an extreme dictatorship. What does it refer to and how could this maintaining of the differences in a principle of fusion and merger of the individual be done? "Unanimous opinion is directed towards allowing differences in practice and that the unity must be based on the lowest common denominator."[ 10] One thing that everyone agrees with is that this unity does not mean uniformity. It does not mean that all Christians should simply become Southern Baptists, Roman Catholics, Greek Orthodox, or whatever - and that this unity should allow a variety of worship styles, devotions, organizations, etc. ${ }^{[1]}$

Any form this organic unity would adopt - of merging various denominations into an evolving organism, of associating groups that essentially have the same confessional standard, of separating from a denomination to form another group with a tradition and liturgy similar in essence, or, finally, even of the schism phenomenon can be referred to it should nevertheless allow the preservation of elements of particularism beyond the aspects of uniformity. This preservation of particular elements refers to the public service in the present case, in addition to the common homogeneous core, based on which the organic merger was merged, the fusion of the particular denominations.

The issue of the autonomy of congregations merged ${ }^{[12]}$ on various issues (usually theological terms or customized practice of the divine public service) has also been raised, but as the purpose of the merger is accurately established and the realization of this union in the unity of the Word of God is soaked, we realize the inconsistency of such claims of autonomy of local churches to the paternal ecclesial authority. But this aspect has its limitations too, because the proclivity towards schism is very great, and the autonomy - in any way it would be - "is condemned to lead to self-empowerment."[13] That is why, on many occasions, the greatest enemy of this movement were even the congregational churches stationed against the organic union and declared to be rather in favor of "continuing the Congregationalist movement" to choose independence. ${ }^{[14]}$

\section{Ecumenism - for what purpose?}

It is important to carefully outline the objectives of this Congregationalist fellowship, because such a movement, which is desirable to be of a global scale, universalist in the Christian Church, cannot only aim at uniting for the sake of union. "It is difficult to justify dedicating time, human and financial resources to activities that do not contribute, at least indirectly, to evangelism."[ 15] Therefore, beyond the declared "loud and clear" purpose of Christian unity, as a response to the desire expressed by Christ in the final prayer in the Garden of Gethsemane, that "all may be one, Father, just as you and I, are one... so that they may be brought to complete unity" (John 17:20, 22, 23), there are other strategic goals to be provided at each stage of "union." In other words, our goal should be a return to the original objectives of the ecumenical movement, because not everyone saying "Lord, Lord" is truly one of His (Math. 7:21).

The issues raised by such union are at hand to be noticed and understood, especially when, as an experiment, you put together some representatives of local congregations without ecumenical experience or subliminal interests. The dialogue between them will fail either in 
theological, ecclesiological, methodological or teleological issues. For anyone who has reservations about the ecumenical movement, the first field of thought is theology. This is because the separation of denominations originally occurred precisely because of theological differences. So, with regard to the theological basis, all members or non-members of ecumenism are reconciled with the idea that theology is the smallest common denominator of the movement. That is because all the other revised or intuited issues are just sub-points of the theological issue. These "obstacles" over which everybody proposes to overlook, but no one is willing to renounce his peculiarity, have always led in fact to the failure of the ecumenical movement and to the utopian character of all these perpetual attempts.

The ecclesial significance of the nature of Christianity suffers from the definition of the term church. Does it first apply to a local congregation of believers, a denomination or an alliance between denominations? Then there are methodological problems, of determining the hierarchical leadership structure and the ultimate value of its decisions towards the concerned communities, as well as other problems attributable to the purpose and strategy of the Church, the character and degree of social and political involvement, and the relationship between the State and the Church. But the least, the teleological problem $^{[16]}$, raises the real question: what is the ultimate goal of the ecumenical movement? Is it the organic fusion of all denominations in one mega Church? Would this one singularity be beneficial to anyone, and how could it actually be done for theologians, leaders, but especially for simple believers? New centrifugal movements have often occurred because of the inertia of believers to keep their original creed and not to drift the "conversion plan" edited by their religious leaders. It is obvious to everyone the utopia of this desideratum, a complete and globalist fusion that seems to have only unfortunate consequences. The affiliation to a certain church would become meaningless, and "organic unity with particularities" would allow and legitimize the "interconfessional pilgrimage" also favored by the inexpressive and useless use of the term "heretics." On the other hand, "an additional problem such a mega-Church raises is that it would be considered the exclusive tenure of Christianity. Believers would be forced to believe that no one can be a Christian outside the visible Church. What then happens to someone who is in the position of a dissident or nonconformist? A monolithic structure would exclude the system of inspections and balances that is equally necessary in a church as it is in secular politics." [17]

Some dialogues and movements prefer to work towards short-term goals, such as mutual understanding on specific topics or working together for charity and justice. "Probably the most relevant question raised by the conservative evangelicals was whether the ecumenical movement did not focus its energies too much on social and international issues, neglecting the primordial task of missionary and evangelization." ${ }^{[18]}$ All of these are good, but they are just a part of the general picture. And so it is assumed that the movement of the interreligious dialogue was initiated.

\section{INTER-RELIGIOUS DIALOGUE AND THE ECUMENICAL MOVEMENT}

It is certain that overlapping the utopia of the ecumenical movement - with which it was often confused to or put into its continuity -, DIR was also easily enveloped by the feelings with which ecumenism was received. It inherits thus its disadvantages, circumspection, and reservations of the audience. If the central purpose of the MEC 
is to form a "unity in diversity" through the merging of particular congregations, this "fear" has also been inoculated to those invited to interreligious dialogue, namely that the ultimate goal of these new, venturesome attempts will be also the "Corruption" of the particular creeds and trying to attract participants to another, diverse or new faith. But things are not that way. Apart from the fact that DIR has nothing to do with MEC, it is neither a descendant, nor a follower, nor a reediting; it is a new movement with its own foundations, purposes, and methods.

Still, if the two movements are not necessarily antagonistic [however, they are not incompatible in all respects], but only distinct, separate, then what is their true relationship and especially why is it not necessary to overlap them? This overlap was sometimes made even by the partisans of the new movement, both by their lack of tact and an own method, as well as their naive desire to help the audience making a mental connection with something previously debated and already active. Occasionally, this overlap was also the effect of combinatorial formulations, of making some (real or sometimes artificial) relationships or common notes between the candidates at the DIR, which correspond subsequently the pretexts necessary for the formation of bridges between the participants in the DIR.

A good example in this regard was the quasi-used phrase of the "religions of the book" (referring to the Mosaic and Christian religions, and sometimes to Islam ${ }^{[19]}$ ), or "Abrahamic religions" or "monotheistic" (referring to the Mosaic, Christian, and Islamic religions and others). These syntaxes and correspondences, despite their real, substantial existence, show a lack of methodical depth and inopportunity in the overall vision of the DIR. This is because any correspondence would be found or formulated between the partners of a particular DIR, they will always overlap that specific DIR with the ecumenical movement, transferring its utopia and its vices of substance, that is, exclusivity, bias and indulgence for other religions, effects that have nothing to do with the correspondences enunciated at that particular dialogical table. In other words, methodologically speaking, it is counterproductive and dangerous to say "we, the people gathered at this interreligious dialogue table, are all ... (something that has in common)", remarking a particularly common feature, whatever that is (except maybe the adulators of "the same" God); for example. Evangelists, Christians, monotheists, liberals, that we share revelation, priesthood, baptism, we use the same formulas, liturgical vessels, the same evangelistic mission, etc. Any particularity is highlighted, it restricts the group of those who can participate in that dialogue around that feature, excluding all others who remain strangers both in the case in question and in the particular DIR. It would be similar to saying that American, African or Australian researchers are welcome to attend a summit of European researchers. It is nonsense trying to incorporate heterogeneous elements towards a declared unitary content around a certain feature that directs the attention exclusively to certain elements which possess that feature. And this happens despite the fact that the phrase "bearers of universality" [transcendental and transhistorical] is inserted on the MEC frontispiece, offering instead a very narrow range of possible participants around the most elective "only one" formulation ${ }^{[20]}$.

Interreligious dialogue, unlike the ecumenical movement, is not about what we have in common, but about what we have differently, which makes us remarkable, what are our special peculiarities. And that is precisely because the purpose of the DIR is altogether different from that of ecumenism. 
If the later is in search of correspondence to create a common desideratum and it exaggerates the importance of union, DIR antithetic promotes the divergence, heterogeneity, individuality, singularity of participants precisely because it wants to create an infinite open, unlimited by any particular determination. The aim is no longer, technically speaking, to formulate a common element, but to establish principles of mutual recognition and interrelation between the various religious traditions, namely for the acceptance of their diversity, without subsequently transforming them into a composite, but on the contrary to valorize them individuality and preserves the particular reality. Otherwise, if a common cause is to be found, the DIR will always have to apply to private cases, for nonantagonistic religious groups, seeking and establishing egalitarian relations, and not inhomogeneous interference.

Many initiators of DIR indulge this kind of dialogue precisely because of their inadequacy of DIR principles and its general objective, which makes their initiative perpetuate the MEC's results and amplify the circumspections and reservations of the audienceexactlyas Isaid.DIRisnotlookingfor separatist mixes and systemic distributions of "n taken by k" religious expressions, but wishes to bring into dialogue as many as possible without establishing anything in common, but precisely to value their particularities and celebrate the diversity of forms of expression their religiosity by bringing together all forms at a common table of dialogue, mutual recognition and acceptance.

\section{CONCLUSION}

If we assign ecumenism with the mathematical function of L.C.M. (the Lowest Common Multiple) because of his endeavor to recognize in his followers common things, DIR is exactly the opposite, i.e. G.C.F. (the
Greatest Common Factor) due to inclusivism on which it is based and which corroborates all the particular formulas in an elaborate and all-encompassing encyclopedia of religious phenomena. The first simplifies all the elements involved until it reaches a common trait to cling to the subsequent merger, the other attracts and valorizes all the non-communal features to amplify the richness of human and religious diversity. The first seeks for equivalences as the basis of interrelation between participants, the other deepens pluralism and develops the vision of the "other" religious as the basis for stimulating interpersonal experiences. "Interreligious dialogue allows us to applaud the differences and, at the same time, to clarify what we share." ${ }^{21]}$ The MEC, therefore, seeks the unity of those who share a common belief, while DIR seeks to join as many religious formations as possible; the first is addressed to small groups, particular cases called upon to give up individual accidents and emphasize only common features, while the other brings together the fullness of the religious phenomena in their entirety and without leaving anything aside while entering into dialogue.

I have exaggerated this antagonism between MEC and DIR out of the desire to clarify once and for all the discrepancy between their purposes, and the methods that should be used by the partisans of each movement, so as not to confuse them and thus bring disadvantages one to another. The first one searches for similar entities; the other celebrates diversity. Thus none can be declared vicious or malicious (at least for the sake of diversity).

The present world is indubitable pluralistic, and the interaction between individuals belonging to the various religious traditions is impossible to dispute and obstruct - than only to the detriment of the one who is trying this occlusion nowadays. "However, the truth is that most of us know 
very little about religions beyond our own traditions. This deficiency of knowledge can easily lead to a lack of communication between those of different beliefs. Due to this lack of connection in a pluralistic world, the need for interreligious dialogue has become an indisputable necessity. Only through interaction will we get to better understand one another. Collaboration through interreligious dialogue allows our world not only to embrace our likenesses but also to celebrate our differences. "[22]

The "path" of the interreligious dialogue was born out of more than the failure of the utopia of ecumenism - from the desire of religious leaders and the civil requirement of peace in the whole religious "field". This "harmonization" has nothing to do with the merging of missionary ecumenism, it is simply the aspiration of peaceful, harmonious coexistence among the adepts of all religious beliefs, not trying to circumscribe each other, but to understand and subsequently accept each other for what they already are, and not for something that could become. This is the DIR creed manifestation and the principles in which the DIR movement is organized and lead into action, as well as my creed of making theology.

\section{BIOGRAPHY}

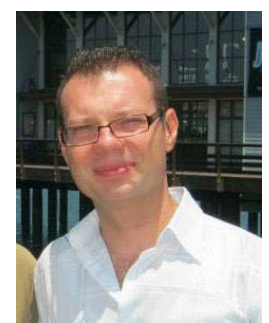

$\begin{array}{ll}\text { Ciocan } & \text { Tudor } \\ \text { Cosmin, born in } \\ \text { Constanta/ Romania in }\end{array}$ 1977, I have attended several theological and psychological schools (BA, MB, Ph.D.), obtained my Ph.D. in Missiology and Doctrinal Theology in 2010. I was ordained as an Orthodox priest in 2002. A high-school teacher from 1998, then Professor assistant and Lecturer from 2012, I have written more than 30 papers on theology and psychology, along with four single-author books in the past two decades.

In 2013 I started a multidisciplinary program aiming to engage scholars from different files into friendly and academic debates with theology and in the same year a Research Center was founded in Ovidius University with researchers from 11 fields. In less than one year, I manage to gather people from around the globe around this idea, and so we have started Dialogo Conferences project. In 2014 I received a Fulbright scholarship, and I spent the summer California and 4 other States in the USA, gathering data and understanding how religious pluralism is possible at a high level of involvement; at the same time I made friends from many different countries and religions that are now involved in this project or another, helping in his endeavor. I have taught and professed interfaith ever since in many visiting professorships I was involved or invited to engage abroad or within Romania.

\section{REFERENCES}

[1] Cf. Millard J. Erickson, Teologia creștină (Eng., Christian Theology), Oradea: Ed. Cartea Creștină, 2004, 977. Also see S. Wesley Ariarajah, „Dictionary of the Ecumenical Movement article on Interfaith Dialogue", in $W C C, 2002$. Retrieved from https://www. oikoumene.org/en/resources/documents/wccprogrammes/interreligious-dialogue-andcooperation/interreligious-trust-and-respect/ ecumenical-dictionary-interfaith-dialogue, accessed at 20.3.2019. He refers to the World Missionary Conference in Edinburgh.

[2] Gheorghe Istodor, Iubirea creştină şi provocările contemporane (Eng., Christian love and contemporary challenges), București: Ed. Sigma, 2006, 245.

[3] Ioan-Gheorghe Rotaru, "Momente istoricofilosofice în apariţia ecumenismului românesc", Alma Mater Porolissensis, Universitatea "Vasile Goldiş" Arad, filiala Zalău, (2001), an II, nr. 3, 79-81.

[4] Stig Hanson, The Unity of the Church in the 
New Testament: Colossians and Ephesians, Lexington: American Theological Library Association, 1963, 109-111.

[5] See Millard J. Erickson, Teologia creștină, Oradea: Ed. Cartea Creștină, 2004, 975-976.

[6] Ioan-Gheorghe Rotaru, "Globalization and its effect on religion", Journal for Freedom of Conscience (Jurnalul Libertății de Conştiinţă), Tome 1, No 1, 2014, 532-542.

[7] For example the United Church of Christ 1957, the United Church of Japan 1941, the Church of South India 1947, the United Reformed Church of Great Britain 1972, the United Church of Canada 1925, the United Church of Christ of the Philippines 1948 and other.

[8] Erickson, Teologia creștină, 976.

[9] For example Erickson, Christian Theology; Albert J.D. Walsh (edit.), United and Uniting: An Ecumenical Ecclesiology for a Church in Crisis, Eugene (Oregon): WIPF \& Stock, $2011 ; \ldots$

[10] Erickson, Teologia creștină, 976.

[11] Andrew Boyd, B.A. Theology \& Philosophy, University of Notre Dame (2000), „What is the main purpose of ecumenical movements?" in Quara, Retrieved from https://www. quora.com/What-is-the-main-purposeof-ecumenical-movements, accessed at 23.3.2019.

[12] Albert J.D. Walsh (edit.), United and Uniting: An Ecumenical Ecclesiology for a Church in Crisis, Eugene (Oregon), 24-31.

[13] Vezi și Papa Benedikt XVI, Joseph Cardinal Ratzinger, Church, Ecumenism, and Politics. New Endeavors in Ecclesiology, Ignatius Press, 2011 (Kindle version), cap. 5.

[14] Gerard Mannion, Lewis S. Mudge (edit.), The Routledge Companion to the Christian Church, Routledge, 2008, 222.

[15] Erickson, Teologia creștină, 984.

[16] William R. Estep, Baptist and Christian Unity, Nashville: Broadman, 1966, 185.

[17] Erickson, Teologia creștină, 984.

[18] W.A. Vissert Hooft, „The General Ecumenical Development Since 1948", in The Ecumenical Advance: A history of the Ecumenical Movement, vol 2, 1948-1968, Harold E. Frey (edit.), Philadelphia: Westminster, 1970, 19.

[19] The syntax is originally Islamic, from the Arabic term 'Ahl al-Kitāb, referring to Jews, Christians and Sabians and is sometimes applied to members of other religions such as Zoroastrians. John L. Esposito (ed.), "Ahl al-Kitab". In The Oxford Dictionary of Islam. Oxford: Oxford University Press, 2014. doi:10.1093/acref/9780195125580.001.0001. ISBN 9780195125580. Accessed 2.4.2019.

[20] Marianne Moyaert and Joris Geldhof(editors), Ritual Participation and Interreligious Dialogue. Boundaries, Transgressions and Innovations. London: Bloomsbury Academic, 2015, 143.

[21] Michael Stephen Kosik, Interreligious Dialogue in Theory and Practice: The Development and Implementation of an Interreligious Retreat. Bringing Together Children of Different Faiths Through Life Experience, online published, May 2017. Retrieved from https://archive.org/details/ CST_Kosik_InterreligiousDialogueInTheory AndPracticeTheDevelopmentAndImplementati, accessed at 27.3.2019.

[22] Ibidem, ii. 